\section{Application of Two Microbial Teas Did Not Affect Collard or Spinach Yield}

\author{
Sharon J.B. Knewtson, Jason J. Griffin, and Edward E. Carey ${ }^{1}$ \\ Department of Horticulture, Forestry, and Recreation Resources, Kansas \\ State University, Manhattan, KS 66506
}

Additional index words. Efficient Microbes ${ }^{\mathrm{TM}}$, effective microbes, manure tea, compost tea, microbial biomass

\begin{abstract}
Microbial tea from a commercial source and a homemade manure tea were evaluated for 2 years under organic and conventional fertility regimens. Testing with different fertility regimens allowed broader assessment of tea efficacy. Collard green (Brassica oleracea L. var. acephala cv. Top Bunch) yield and soil microbial activity were measured after microbial tea applications were made in three fertility treatments (conventional, organic, or no fertilizer amendment) on a previously unfertilized sandy loam soil. Spinach (Spinacia oleracea L. cv. Hellcat) and collard green yields were determined after commercial microbial tea application to a silt loam soil previously managed with organic or conventional vegetable crops in open fields and under high tunnels. Results indicated that nutrient additions influenced crop yields, even doubling yield. This demonstrated that improved nutrient availability would affect yield at the chosen locations. However, microbial tea applications did not affect crop yield. These results did not support the hypothesis that microbial tea improves plant nutrient uptake. Additionally, soil microbial respiration and biomass were unaffected after two or three tea applications.
\end{abstract}

Compost tea is a term used to refer to an aqueous solution produced using composted animal or vegetative matter. Over 10,000 customers have purchased equipment for home production of compost tea in the United States (Carpenter-Boggs, 2005). Interest was fostered mostly by anecdotal evidence shared in newsletters and specialty publications targeting home and smaller market fruit and vegetable producers. Compost tea may or may not be actively aerated during production. Amendments to tea such as molasses, cane syrup, or fruit are intended to facilitate multiplication of microbes beneficial to crops (Ingham, 2000). Most compost teas are filtered to remove the compost but retain the microbes that were grown in the composting

Received for publication 4 Aug. 2008. Accepted for publication 23 Oct. 2008.

Contribution No. 09-167-J of the Kansas Agricultural Experiment Station.

We thank Paul White (USDA soil scientist, former manager of Kansas State University soil microbiology laboratory) for instruction in analysis of microbial biomass and allowing use of laboratory facilities. Efficient Microbes (EM) ${ }^{\mathrm{TM}}$ original solution was donated for this study by Sustainable Community Development, L.L.C. (Kansas City, MO). Trees for Life (Wichita, KS), a nonprofit agriculture and educational organization, aerated the cow manure slurry with fresh bakers yeast donated by the American Institute of Baking, Manhattan, KS. Assistance with the planting and maintenance of the collard crops by the J. C. Pair Horticultural Center of Kansas State University staff (Tami Roesch, Richard Ryer, and Mike Shelton) is greatly appreciated. We are grateful to the Trees for Life staff volunteers who harvested collards.

${ }^{1}$ To whom reprint requests should be addressed; e-mail tcarey@ksu.edu. and brewing (Ingham, 2000). Compost tea is thought to act more as a microbial inoculant that stimulates soil or foliar microbial population effectiveness than as a nutrient source (Carpenter-Boggs, 2005).

Claims of benefit from compost-steeped microbial tea are broad and include improved crop yield, vigor, quality, and resistance to diseases and pests (Carpenter-Boggs, 2005; Grobe, 1997). However, variable effects from a variety of tea production and application methods have been reported. Several foliar pathogens were reported to be suppressed by aerated and nonaerated microbial teas (Scheuerell and Mahaffee, 2002). Early blight [Alternaria solani (Ell. \& Mart) L.R. Jones \& Grout] of tomato (Lycopersicon esculentum Mill.) and purple blight [Alternaria porri (Ellis) Cif.] of onion (Allium cepa L.) were suppressed by a nonaerated compost tea (Haggag and Saber, 2007). Compost tea application may not be consistently beneficial. Compost tea applied to potato (Solanum tuberosum L.) increased incidence of silver scurf (Helminthosporium solani Dur. \& Mont.) and black scurf (Rhizoctonia solani Kuhn), but did not affect incidence of dry rot (Fusarium sp.), common scab [Streptomyces scabies (Thaxter) Waksman \& Henrici], early blight, bacterial soft rot [Erwinia carotovora var. carotovora (Jones) Dye] (AlMughrabi, 2006), or late blight [Phytophthora infestans (Mont.) deBary] (Sturz et al., 2006). Some compost tea formulas increased yield of broccoli (Brassica oleracea var. italica Plenck) (Sanwal et al., 2006), onion, and tomato crops (Haggag and Saber, 2007). Compost teas prepared with chicken manure consistently reduced disease and increased yield of onion and tomato crops (Haggag and Saber, 2007). However, not all tea formulas increased yield (Al-Mughrabi, 2006; Haggag and Saber, 2007).

Commercially available microbial sources may replace compost as an inoculant and could simplify compost tea production. These may also decrease variability (Scheuerell and Mahaffee, 2002) between batches and alleviate human health concerns about pathogens (Kannangara et al., 2006) in compost tea. A class of microbial teas was developed by Teruo Higa, Professor of Horticulture at the University of the Ryukyus, Okinawa, Japan, and contains what he called "effective microorganisms." These commercial products contain selected species of microorganisms, which are predominantly lactic acid bacteria and yeasts, and smaller numbers of photosynthetic bacteria, actinomycetes, and other organisms (Higa and Parr, 1994). Higa hypothesized that by increasing microbial diversity of soils, effective microorganisms improve soil quality, enhance crop production and quality, and create a more sustainable environment.

The benefits of effective microbes have been demonstrated in crop systems in Japan, China, Sri Lanka, India, Bangladesh, and Brazil. Research reported yield increased by soil application of effective microbes in combination with organic and conventional fertilizers in tomato (cv. Momotaro T96) (Wang et al., 1999), sweet orange (Citrus sinensis Osbeck cv. Pera) grafted to lemon rootstock (Citrus limonia Osbeck cv. Cravo) (Paschoal et al., 1998), onion (cv. Taherpur), and string bean (Vigna sesquipedalis L. cv. Topgreen) (Chowdhury et al., 1996). Yield increase was related to increased fruit set (Wang et al., 1999) and increased total chlorophyll content (Chowdhury et al., 1996).

The reported effects of effective microbes on soil include increased nutrient availability (Sangakkar and Weerasekera, 2001); increased aggregation, porosity, and water infiltration (Tokeshi et al., 1996); and increased organic matter, $\mathrm{pH}$, and cation exchange capacity (Paschoal et al., 1998). Effective microbes in a rice bran carrier (EM Bokashi) was reported to increase rice (Oryza sativa L.) grain yield; this was associated with increased soil organic matter content, microbial biomass, and available nutrients as well as improved soil porosity and permeability compared with organic and chemical fertilizer treatments without effective microbes (Shao et al., 2003)

Manure teas are another variant on the concept of compost tea. The product may serve only as a diluted liquid fertilizer (Diver, 2005), but it is hypothesized by some to be a potential stimulant of indigenous soil microbial populations (Jim Barlow, agronomist and commercial producer of microbial products, personal communication). A tea is made from a solution that contains animal manure. Multiplication of microbes from the manure is encouraged by aeration and additives, which may include a sucrose source and yeast to help diversify the microbial population. However, the soil environment is probably not optimal for many of the microbial 
organisms in the manure tea, which are consumed by indigenous microbes. Manure tea is hypothesized to be beneficial not because of individual ingredients, but like compost tea, because of the microbial population grown in the tea.

Variability in microbial tea effects is probably attributable, in part, to variation in tea production methods. Ingredients, brew conditions (aeration, temperature, and time), application rate, frequency, and mechanism may all vary (Scheuerell and Mahaffee, 2002). It is also hypothesized that microbial tea effects may vary by crop, season, and soil condition (Carpenter-Boggs, 2005). This variability discourages scientific investigation and publication despite positive anecdotal reports. Improved yield is an important consideration for growers waiting to review credible evidence of microbial tea benefit.

This study evaluated the effect of two microbial teas made from: 1) a homemade manure tea recipe; and 2) a commercially available microbial source. The selection was because of interest on the part of Kansas State University research and extension clientele. The commercial product was an effective microbe culture produced in our region by a former student of Teruo Higa with the trade name Efficient Microbes ${ }^{\mathrm{TM}}$ (Sustainable Community Development, Kansas City, MO). The manure tea recipe was chosen at the request of Trees for Life, a nonprofit agriculture and educational organization with their home office in Wichita, KS. It was considered to be a potential low-cost agriculture input for impoverished tropical regions (Calovich, 2005). A scientific study was desirable before promoting it within their network. We recognize that manure tea application to leafy green vegetables would not meet U.S. Department of Agriculture National Organic Program guidelines, but it is not out of step with producer practices in many developing countries.

It was hypothesized that microbial tea applications improve the soil microbial environment and this would be reflected in improved plant growth. It was also hypothesized that the microbial tea benefit might be affected by nutrient source (organic or conventional fertilizer). The objective of this study was to evaluate the effect of microbial teas made from manure and from Efficient Microbes $^{\mathrm{TM}}$ on crop yield and microbial biomass in a sandy loam soil. The effect of Efficient Microbes ${ }^{\mathrm{TM}}$ on crop yield was also evaluated on a loam soil.

\section{Materials and Methods}

Sandy loam soil site. Experiments were conducted at the John C. Pair Horticultural Center, Haysville, KS, in fall of 2005 and 2006. The soil is a Canadian-Waldeck sandy loam (coarse-loamy, mixed, superactive thermic Udic Haplustolls, and Fluvaquentic Haplustolls). This location was previously managed as unfertilized brome (Bromus inermis Leyss.) pasture since 1991.
Animal manure tea and a commercial microbial tea were tested with the following fertility treatments: 1) conventional fertilizer application; 2) no fertilizer application; and 3) organic fertilizer application. The experiment was a randomized complete block design with a split-plot arrangement of treatments replicated four times. Fertility treatment represented the whole plot factor and microbial tea application was the subplot factor. Whole plots consisted of an incorporated conventional fertilizer, an incorporated
Table 1. Analysis of variance of effects of microbial teas and fertilizers on collard (Brassica oleracea L. var. acephala cv. Top Bunch) crop yield in an open field at Haysville, KS, in 2005 and 2006.

\begin{tabular}{lccc}
\hline & & \multicolumn{2}{c}{$P$ value } \\
\cline { 3 - 4 } Source & df & 2005 & 2006 \\
\hline Tea $^{\mathrm{z}}$ & 2 & 0.8270 & 0.3716 \\
Fertilizer $^{\mathrm{y}}$ & 2 & 0.0018 & 0.0001 \\
Tea $\times$ fertilizer & 4 & 0.9912 & 0.0283 \\
\hline
\end{tabular}

${ }^{\mathrm{z}}$ Manure tea, Efficient Microbes (EM), or no tea application.

yOrganic, conventional, or no fertilizer application.
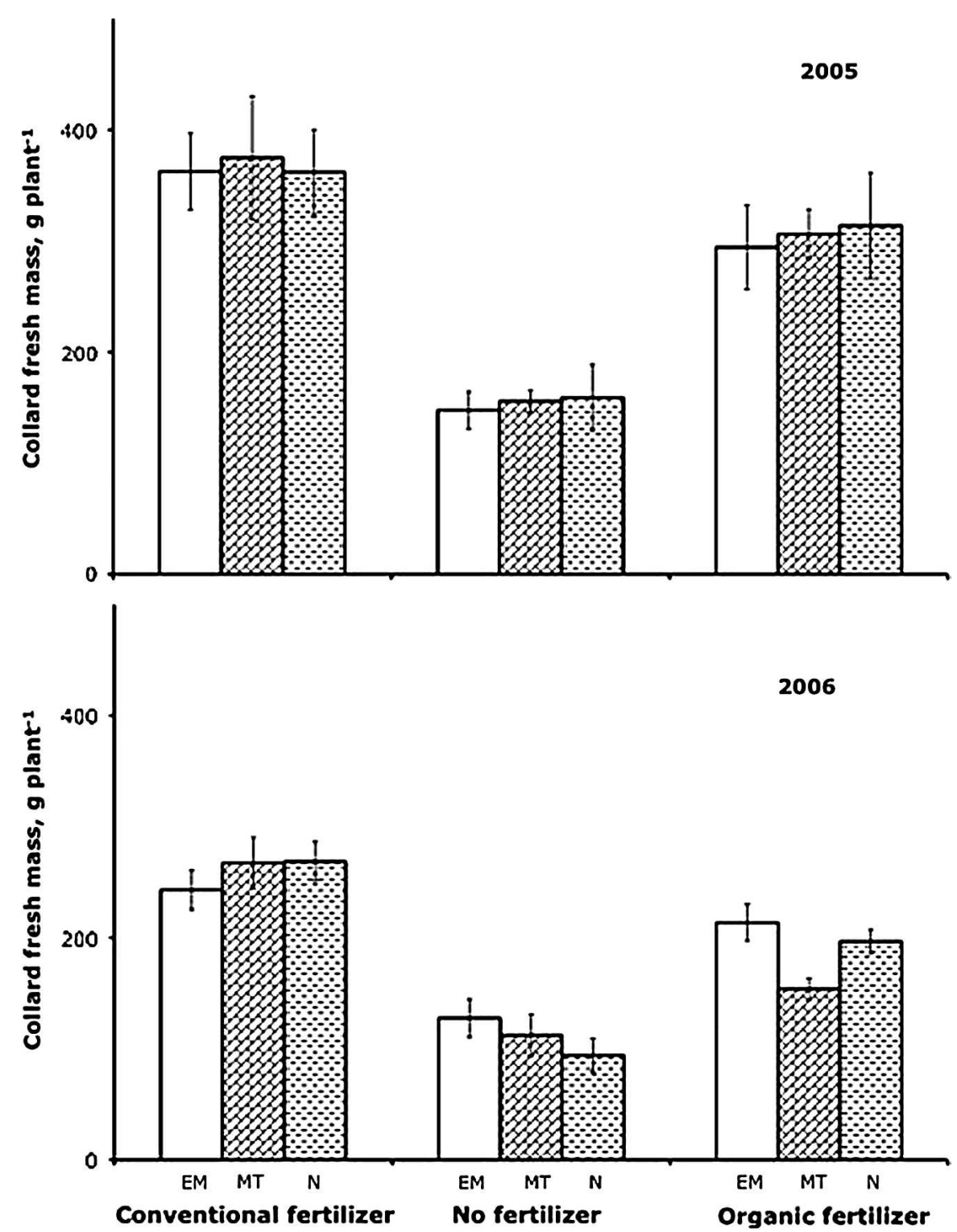

Fig. 1. Fresh yield of whole collard plants with applications of commercially available microbial tea (EM), animal manure tea (MT), or no tea $(\mathrm{N})$ in three nutrient management systems (conventional, no fertilizer, and organic fertilizer applied) grown at Haysville, KS, in 2005 and 2006. Error bars represent SEs of means of four replicates.

organic fertilizer, or an unamended control. Subplot treatments were an animal manure tea (MT), a commercial microbial tea (EM), or a nontreated control. Individual subplots were $10.5 \mathrm{~m}^{2}$ in size. Treatments were repeated in the same plots the second year.
The commercial microorganism culture (EM) was prepared according to the manufacturer's directions (Sustainable Community Development, L.L.C., Kansas City, MO). To make $10 \mathrm{~L}$ of tea, $0.47 \mathrm{~L}$ Efficient Microbes $^{\mathrm{TM}}$ and $0.47 \mathrm{~L}$ unsulfured molasses 
were added to $10 \mathrm{~L}$ deionized water. Brer Rabbit or Grandma's molasses (B\&G Foods, Inc., Roseland, $\mathrm{NJ}$ ) was used. The solution was incubated at $32{ }^{\circ} \mathrm{C}$ for 4 to $7 \mathrm{~d}$ in a sealed plastic container with little headspace.

Homemade animal manure tea (MT) was made according to directions provided by Trees for Life. To make $10 \mathrm{~L}$ of tea, $480 \mathrm{~g}$ air-dried, chipped dairy cow manure, $37 \mathrm{~g}$ bakers yeast, and $0.5 \mathrm{~L}$ molasses were added to $10 \mathrm{~L}$ tap water. Two 5-gallon buckets of dry dairy cow manure were collected at the Kansas State University research farm holding pens. The manure was chopped with a machete to chips $3 \mathrm{~cm}$ or smaller and then spread on a tarp to further dry before being well mixed. Bakers' yeast was provided by the American Institute of Baking, Manhattan, $\mathrm{KS}$. The slurry was aerated with an Aqua aquarium pump (Aqua ${ }^{\circledR}$ culture; Wal-Mart, Bentonville, AR) with a $1200-\mathrm{cc} / \mathrm{min}$ air flow rate through an air stone for at least $5 \mathrm{~d}$ in an open plastic container.

Microbial tea was applied over crop rows from a watering can at rates of $375 \mathrm{~L} \cdot \mathrm{ha}^{-1} \mathrm{EM}$ $\left(17 \mathrm{~L} \mathrm{EM}^{\mathrm{TM}}\right.$ concentrate/ha ${ }^{-1}$ ) and $187 \mathrm{~L} \cdot \mathrm{ha}^{-1}$ MT during irrigation. Microbial tea applications were made at planting and at 1 and 5 weeks after planting. In 2006, tea applications were also made 3 and 6 weeks before planting as well as at 0,1 , and 5 weeks after planting.

Fertilizer application was intended to follow optimal collard production recommendations while taking preplant soil analysis, texture, and previous management into account. Conventional fertilizer as pelletized 13-13-13 (13N-5.7P-10.8K) (Propell; Farmland Industries, Kansas City, MO) was incorporated into soil to supply nitrogen $(\mathrm{N})$ at a rate of $90 \mathrm{~kg} \cdot \mathrm{ha}^{-1}$ a week before planting and side-dressed at $34 \mathrm{~kg} \cdot \mathrm{ha}^{-1}$ of N 3 and 6 weeks after planting. Organic fertilizer was incorporated into soil a week before planting to supply $\mathrm{N}$ at a rate of $280 \mathrm{~kg} \cdot \mathrm{ha}^{-1}$. Hu-more compost $(1 \mathrm{~N}-0.4 \mathrm{P}-0.8 \mathrm{~K})$ was used in 2005 . Hu-more (Humalfa, LLC, Stattuck, OK) is produced from aerobically composted cow manure and alfalfa. Bradfield organic fertilizer $(3 \mathrm{~N}-0.4 \mathrm{P}-4.1 \mathrm{~K})$ was used in 2006 . Bradfield Organics (Springfield, MO) fertilizers contain alfalfa, molasses, sulfate of potash, poultry byproduct meal, and humates.

The crop used was collard greens (Brassica oleracea L. var. acephala cv. Top Bunch) obtained from Johnny's Selected Seeds (Albion, ME). Seeds were sown in a greenhouse 1 month before transplanting to the field. Collard seedlings were transplanted 0.4 $\mathrm{m}$ apart in rows spaced $0.9 \mathrm{~m}$. Each plot included three rows of seven plants. Rows had three buffer plants between plots and at row ends. Transplant dates were 25 Aug. 2005 and 14 Sept. 2006.

The crop was drip-irrigated with one line per row. Drip tape had a flow rate of $2.5 \mathrm{~L} \cdot \mathrm{h}^{-1}$ per meter with emitters spaced $30 \mathrm{~cm}$ (Roberts Ro-Drip; Roberts Irrigation Products, San Marcos, CA). Weeds were controlled by hoeing. Caterpillar damage was controlled with Bacillus thuringiensis (Dipel; Valient

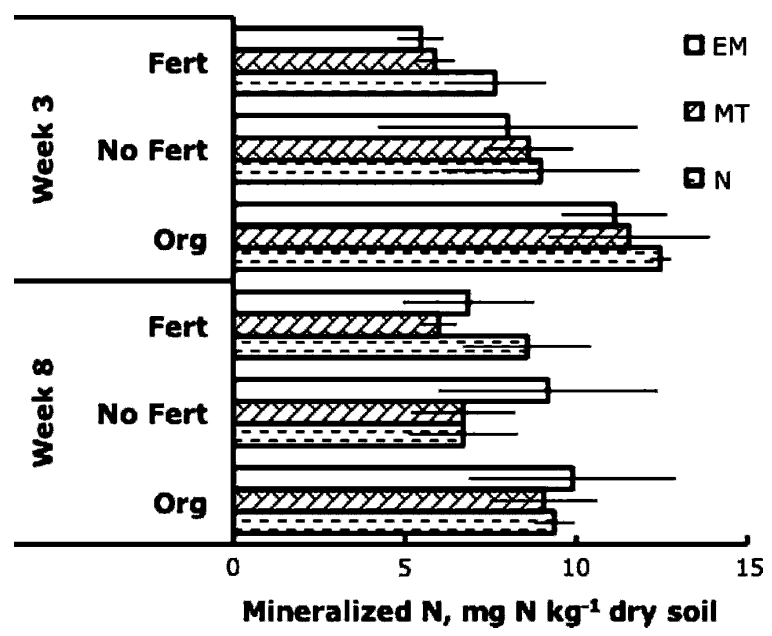

Fig. 2. Nitrogen mineralized during $11 \mathrm{~d}$ incubation from soil treated with applications of commercially available microbial tea (EM), animal manure tea $(\mathrm{MT})$, or no tea $(\mathrm{N})$ in three nutrient management systems (conventional, no fertilizer, and organic fertilizer applied) at Haysville, KS, 2005. Soil was collected at Weeks 2 and 8 of the experiment and tea applications were made on Weeks 0,1 , and 5 . Error bars indicate sEs of means of four replicates.

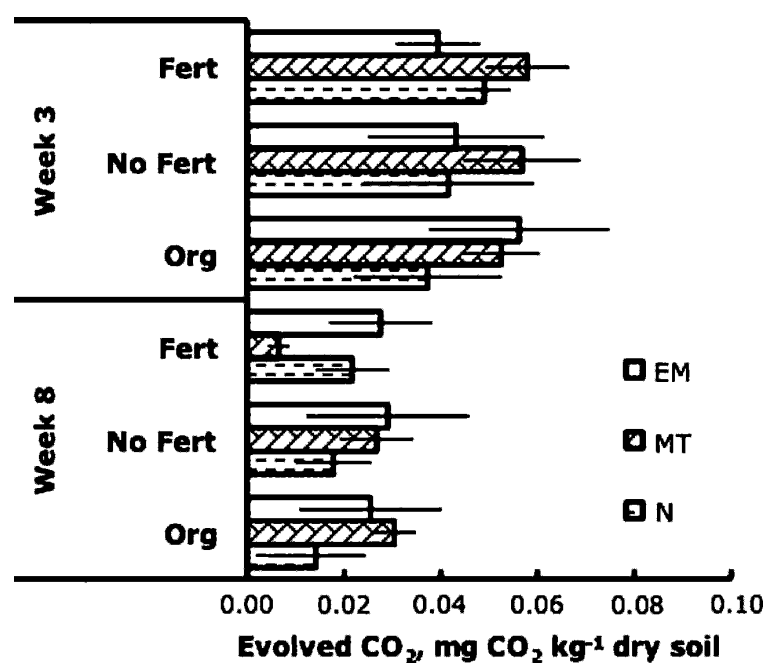

Fig. 3. Carbon dioxide evolved during $11 \mathrm{~d}$ incubation from soil treated with applications of commercially available microbial tea (EM), animal manure tea (MT), or no tea $(\mathrm{N})$ in three nutrient management systems (conventional, organic, or no fertilizer applied) at Haysville, KS, 2005. Soil was collected at Weeks 3 and 8 of the experiment and tea applications were made on Weeks 0, 2, and 5. Error bars indicate sEs of means of four replicates.

BioSciences Corporation, Libertyville, IL) applications as required. Pest incidence was low. Disease was not observed.

A cover crop of sorghum sudangrass $\{[$ Sorghum bicolor (L.) Moench $] \times[S$. sudanense (Pipe) Stapf.]\} was grown in the summer before the second experiment. Sorghum sudangrass seed was obtained from Albert Lea Seed House (Albert Lea, MN) and planted 24 May 2006. It was mowed to $\approx 30 \mathrm{~cm}$ height through the summer. Mowed clippings were not removed. In late August, the sorghum sudangrass was mowed to the ground.

Soil microbial respiration and nitrogen mineralization were measured in 2005. From this, microbial biomass was calculated. Biomass measured by fumigation is well correlated to that measured by microscopy and soil ATP analysis methods (Vance and Brooks,
1987). Soil samples were collected from each plot 1 week after the second microbial tea application ( 2 weeks after planting) and again at harvest ( 8 weeks after planting). Soil was fumigated and incubated according to methods described by Horwath and Paul (1994). Soil $(25 \mathrm{~g})$ moistened to approximately field capacity was preincubated at $35^{\circ} \mathrm{C}$ for $3 \mathrm{~d}$ and then $25^{\circ} \mathrm{C}$ for $4 \mathrm{~d}$ before fumigation. Samples were fumigated overnight with ethanolfree chloroform. Chloroform was evacuated the next day. Chloroformed samples and nonchloroformed controls were incubated for $11 \mathrm{~d}$ at $25{ }^{\circ} \mathrm{C}$. Evolved $\mathrm{CO}_{2}$ was measured using a Shimadzu gas chromatograph (GC-8A; Shimadzu Scientific Instruments, Columbia, MD). Inorganic soil nitrogen was extracted from the 25-g soil sample with $100 \mathrm{~mL}$ of $1 \mathrm{M} \mathrm{KCI}$ and measured with an autoanalyzer 
(RFA-300; Alpkem Corp., Clackamas, OR). Soil microbial biomass carbon (C) and $\mathrm{N}$ were compared between treatments. Nitrogen mineralization was measured as the difference between initial soil inorganic $\mathrm{N}$ and that measured in nonfumigated soil after 11-d incubation.

The aboveground portion of collard plants was harvested 8 weeks after transplanting by cutting the stem at the soil surface and obtaining a fresh weight in the field. Mean yield differences were analyzed between microbial tea treatments within fertility treatments. Analysis of variance was calculated using SAS 9.1 (Statistical Analysis System Institute, Cary, NC) holding block and block by fertilizer as random effects.

Silt loam soil site. Experiments with application of the commercially available microorganism culture (EM) were conducted at the Kansas State University Research and Extension Center, Olathe, KS, in 2005 and 2006. The experiment was conducted in high tunnels and adjacent field plots. The soil is a Kennebec silt loam soil (fine-silty, mixed, superactive, mesic Cumulic Hapludolls). Plots had been managed for either conventional or organic vegetable production since 2002. They were previously managed as an unfertilized brome pasture.

Commercial microbial tea (EM) was thus tested at Olathe in both field and the comparatively protected high tunnel environment in the following crop management systems:

Organic management, with organic fertilizer applied;

Organic management, without fertilizer applied;

Conventional management, with conventional fertilizer applied; and

Conventional management, without fertilizer applied.

Within the conventional and organic production systems, the experiment was $2 \times 2$ factorial with fertilizer and microbial tea treatments. Treatment plots were $1 \mathrm{~m}^{2}$ and replicated in an open field and under high tunnels three times.

Spinach (Spinacea oleracea L. cv. Hellcat), obtained from Seminis, Inc. (St. Louis, MO), was direct-seeded in high tunnels on 11 Oct. 2005 and harvested 22 Nov. by cutting leaves just above the surface and then overwintered and harvested again on 3 Feb. 2006. Collard greens (cv. Top Bunch) were grown in 2006 in high tunnels and adjacent fields. Collards were transplanted on 12 May 2006. Lower collard leaves were harvested on five occasions; 6, 7, 9, 11, and 14 weeks after planting.

Preparation and application methods for EM were the same as for the Haysville experiments. Microbial tea was applied to the spinach crop at planting and then 2 weeks after planting and after each harvest. In 2006, EM was applied to the collard crop at planting, 2 and 5 weeks after planting, and after each of the leaf harvests.

Fertilizer was preplant soil incorporated to supply $\mathrm{N}$ at a rate of $224 \mathrm{~kg} \cdot \mathrm{ha}^{-1}$. Organic

Table 2. Analysis of variance of effects of microbial teas and fertilizers on microbial biomass carbon and microbial biomass nitrogen 2 and 8 weeks after initial microbial tea applications to soil at Haysville, $\mathrm{KS}$, in 2005.

\begin{tabular}{|c|c|c|c|c|c|}
\hline \multirow[b]{3}{*}{ Source } & \multirow[b]{3}{*}{ df } & \multicolumn{4}{|c|}{$P$ value } \\
\hline & & \multicolumn{2}{|c|}{ Week 3} & \multicolumn{2}{|c|}{ Week 8} \\
\hline & & $\overline{\mathrm{MBC}^{\mathrm{z}}}$ & $\mathrm{MBN}^{\mathrm{y}}$ & $\mathrm{MBC}$ & $\mathrm{MBN}$ \\
\hline Tea $^{x}$ & 2 & 0.267 & 0.472 & 0.441 & 0.191 \\
\hline Fertilizer $^{\mathrm{w}}$ & 22 & 0.137 & 0.579 & 0.133 & 0.728 \\
\hline Tea $\times$ fertilizer & 44 & 0.150 & 0.483 & 0.164 & 0.699 \\
\hline
\end{tabular}

${ }^{\mathrm{z}} \mathrm{MBC}=$ microbial biomass carbon.

${ }^{\mathrm{y}} \mathrm{MBN}=$ microbial biomass nitrogen.

${ }^{\mathrm{x}}$ Manure tea, Efficient Microbes (EM), or no tea application.

${ }^{\mathrm{w}}$ Organic, conventional, or no fertilizer application.

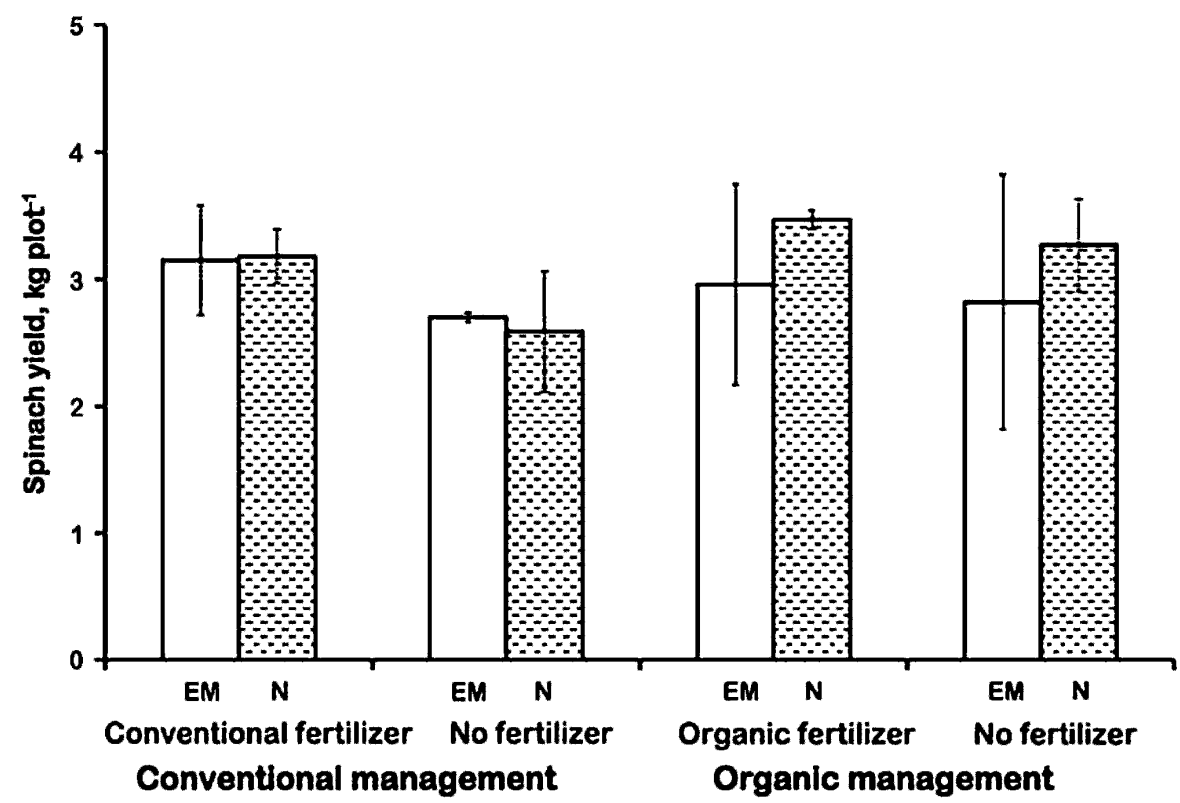

Fig. 4. Spinach yield as affected by fertilizer and microbial tea (EM = commercially available microbial tea, $\mathrm{N}=$ no tea) in conventional and organic management systems on a loamy soil under high tunnels near Olathe, KS, in 2005. Error bars indicate SES of means of three replicates.

fertilizer Hu-more compost $(1 \mathrm{~N}-0.4 \mathrm{P}-0.8 \mathrm{~K})$ was used in 2005 and Bradfield ( $3 \mathrm{~N}-0.4 \mathrm{P}-$ $4.1 \mathrm{~K})$ in 2006 . Conventional fertilizer $(16 \mathrm{~N}-$ 3.5P-6.6K) was pelletized (Loveland Golf Course Starter; Howard Johnson's Enterprises, Inc., Milwaukee, WI). In 2006, an additional $33.6 \mathrm{~kg} \cdot \mathrm{ha}^{-1} \mathrm{~N}$ conventional fertilizer was side-dressed after the third collard leaf harvest. Crops were drip-irrigated in similar manner as the Haysville location, but with two lines of drip tape per crop row. Weeds were manually controlled. Pest and disease incidence were low.

Analysis of variance of harvest means was done using SAS 9.1 (Statistical Analysis System Institute). The mixed procedure was used considering five main factors and their interactions with fresh harvest weights. Statistical factors were: EM application, fertilizer application, nutrient management (conventional versus organic), location (high tunnel and field), and harvest date.

\section{Results and Discussion}

The soils used in these experiments represented nutrient-poor (previously unfertilized sandy loam soil, Haysville, KS) and nutrient-rich (fertilized loam, Olathe, KS) soil conditions. Microbial tea treatment did not produce significant yield improvement in either situation. Like Al-Mughrabi (2006), we did not find yield increases resulting from microbial tea application.

Microbial tea application did not affect collard yield at Haysville, KS, in 2005 or 2006 (Table 1). Visual observations suggested leaf size was affected by fertility treatments but were not obvious for tea treatments. Neither EM nor MT improved fresh plant mass (Fig. 1) or oven-dried mass (data not shown) compared with collard plants that did not receive microbial tea in any nutrient management system in 2005 and 2006. Fertilizer treatment did affect yield (Table 1).

Soil microbial response to tea applications was not detected by analysis of $\mathrm{N}$ mineralization, soil respiration, or microbial biomass C or N. Mineralized N (Fig. 2) and evolved $\mathrm{CO}_{2}$ (Fig. 3) were not significantly affected by microbial tea treatments within conventional, organic, or unamended fertility management systems in soil collected 1 week after the second tea application and soil collected at harvest from Haysville in 2005. 
Variability of carbon dioxide measurements between replicates was as great as that between treatments (Fig. 3). Soil microbial activity, as indicated by changes in microbial biomass $\mathrm{C}$ and $\mathrm{N}$, was not significantly affected by microbial tea applications (Table 2). Our study could not demonstrate a link between microbial tea application and soil microbial activity, which contradicts Shao et al. (2003).

In the second year of the study, 2006, there was a significant tea by fertilizer interaction effect at the Haysville location (Table 1). Single degree of freedom contrasts of collard yield means showed trend differences in the responses to MT versus no tea under organic and no fertilization treatments and in the responses to EM versus no tea under conventional and no fertilization treatments (Fig. 1). There was a trend toward improved collard greens yield with tea application compared with no tea in the absence of fertilizer amendment that was the reverse for MT with organic fertilizer amendment and EM with conventional fertilizer amendment. The yield differences between tea treatments in unfertilized collard greens were not significant. Within fertilizer treatments, the only yield difference of statistical significance was a decline accompanying MT application with organic fertilizer in 2006. Interaction effects were not seen between tea and fertilizer at Haysville in 2005. Data pointing to a possible negative tea $\times$ fertilizer interaction was inconclusive, because it was not seen across combinations of fertilizer and tea and only appeared in one season.

At Olathe, KS, the addition of EM did not significantly improve yield in either conventional or organically managed crops. Yield of spinach grown in high tunnels in 2005 was not significantly improved by EM application regardless of fertilizer or management regime (Fig. 4). (Spinach planted in the field in 2005 germinated poorly and was not harvested.) The application of EM did not significantly improve yield under high tunnels or in adjacent fields in the 2006 season (Table 3) with nutrient amendment and EM applications repeated in the same plots but with a collard green crop (Fig. 5). Within management systems (conventional and organic), yield analysis did not demonstrate microbial tea causing improvement in crop performance (Table 3 ).

There was a significant tea by management interaction in the Olathe high tunnels in 2006 (Table 3). Although total collard green yield was similar in EM-treated plots for organic and conventionally managed high tunnels, collard greens without EM application had comparatively lower yields in conventionally managed than in organically managed high tunnels, particularly in the absence of fertilizer (Fig. 5). This suggests that in a conventional cropping system with limited nutrient reserve, EM application may provide some slight benefit. Paired comparison of collard yield within management systems did not indicate significant differences with and without tea application. The
Table 3. Analysis of variance of effects of microbial tea, fertilizer (seasonal application made or withheld), management system (conventional or organic), and harvest dates on crop yield under high tunnels (HT) and in open field plots at Olathe, KS, in 2005 and 2006.

\begin{tabular}{lcccc}
\hline & & \multicolumn{3}{c}{$P$ value } \\
\cline { 3 - 5 } Source & df & 2005, HT $^{\mathrm{y}}$ & 2006, HT $^{\mathrm{x}}$ & 2006, field $^{\mathrm{x}}$ \\
\hline Tea & 1 & 0.4850 & 0.4504 & 0.8871 \\
Fertilizer & 1 & 0.2807 & 0.0014 & 0.0155 \\
Management & 1 & 0.6923 & 0.4364 & 0.2834 \\
Harvest date & $1,4^{\mathrm{w}}$ & 0.0433 & 0.0001 & 0.0001 \\
Tea $\times$ fertilizer & 1 & 0.8618 & 0.4731 & 0.8915 \\
Tea $\times$ management & 1 & 0.4019 & 0.0365 & 0.3336 \\
Tea $\times$ date & 1,4 & 0.7776 & 0.1170 & 0.3875 \\
\hline
\end{tabular}

${ }^{\mathrm{z}}$ Interactions not presented in the table are not significant, except for fertilizer $\times$ date.

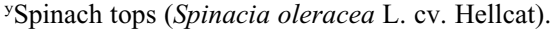

${ }^{\mathrm{x}}$ Collard leaves (Brassica oleracea L. var. acephala cv. Top Bunch).

wTwo leaf harvests in 2005 and five in 2006.
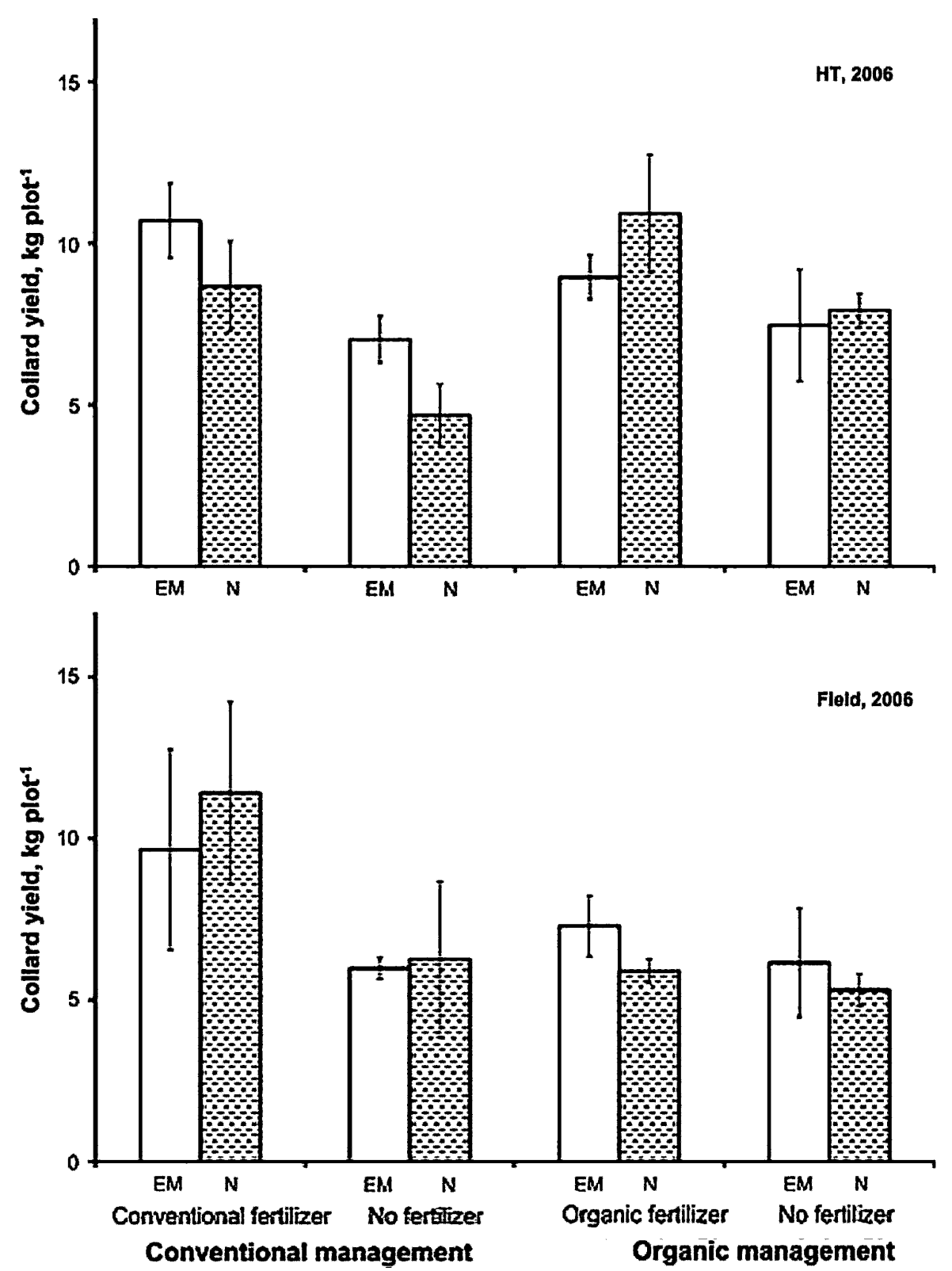

Fig. 5. Collard yield as affected by fertilizer and microbial tea $(E M=$ commercially available microbial tea, $\mathrm{N}=$ no tea) in conventional and organic management systems on a loamy soil under high tunnels and in adjacent fields near Olathe, KS, in 2005. Error bars indicate SEs of means of three replicates. 
tea by management interaction effect was seen in only 1 year, was not repeated in the field, and did not produce tea treatment differences of statistical significance and therefore may not be meaningful.

Neither tea application nor management (conventional versus organic amendments) affected yield at Olathe in 2005 or 2006 (Table 3). There were differences in yield between harvest dates, but there was not an interaction effect between date and tea application. Fertilizer application affected yields in 2006 but not 2005. A fertilizer effect may have been masked in 2005 by residual soil nutrients from previous seasons. The interaction effect of tea and fertilizer application was not significant (Table 3).

The two microbial teas tested did not result in improved crop yields. This was not the result of hindrance by fertilizer source. Treatments included no fertilizer, standard conventional fertilizers, and two organic fertilizers, one a composted product and one an alfalfa base with additives to hasten mineralization. Fertilizer was applied at recommended optimal rates that took into account soil nutrient analysis, texture, and former management. The sandy loam soil was not previously fertilized and so received organic fertilizer at a higher rate than the fertilized loam soil. Conventional fertilizer applications were split on the sandier soil to prevent deficiency later in the season. It is doubtful that a change in fertilizer rate or timing would have altered tea effect results.

Improvement in crop yield resulting from increased nutrient uptake was possible as demonstrated by improved yield of collard crops associated with nutrient amendment (Tables 1 and 3). If nutrient availability had been improved by EM microbial tea application in the current study, as previously reported with rice in China (Shao et al., 2003) and cowpea in Sri Lanka (Sangakkar and Weerasekera, 2001), it should have been reflected in yield differences between treatments with and without microbial tea application.

Results with MT did not justify the conversion of manure to tea. Farmers with nutrient poor tropical soils that have an available manure source are unlikely to gain an advantage by brewing tea rather than simply applying manure to fields.

Growers may choose to apply microbial tea for benefits suggested in other studies (for example, protection from diseases). Our study, however, did not show EM or MT improving short-term yield or microbial biomass. Our studies were limited to two species and locations. Future studies may show microbial tea benefits on yield at other locations or with different crops. Continuation of the study with the same crops and locations may show benefit if trials were continued for a longer period. It is also possible that other tea recipes could be more effective than those that we used.

\section{Literature Cited}

Al-Mughrabi, K.I. 2006. Antibiosis ability of aerobic compost tea against foliar and tuber potato diseases. Biotech. 5:69-74.

Calovich, A. 2005. Local growers to put manure tea to the test. The Wichita Eagle, 31 May 2005. 8 Apr. 2008. <http://globalcircleofknowledge.org/ project/soil/Manure_tea_article.pdf $>$.

Carpenter-Boggs, L. 2005. Diving into compost tea. Biocycle 46:61-62.

Chowdhury, A.R., M.M. Islam, M.M. Hossain, and J. Haider. 1996. Effect of EM on the growth and yield of crops. Third international conference on Kyusei nature farming. Proc. Conf. Santa Barbara, California, 5-7 Oct. 1993. p. 132-137.

Diver, S. 2005. Supplemental resources on effective microorganisms (EM) and indigenous microorganisms (IMO). ATTRA-National Sustainable Agriculture Information Service. $31 \mathrm{Mar}$. 2008. <http://attra.ncat.org/attra-pub/composttea-notes.html>.

Grobe, K. 1997. It's a new era for farm compost. Biocycle 38:52-54.

Haggag, W.M. and M.S.M. Saber. 2007. Suppression of early blight on tomato and purple blight on onion by foliar sprays of aerated and nonaerated compost teas. J. Food Agr. Environ. 5:302-309.

Higa, T. and J.F. Parr. 1994. Beneficial and effective microorganisms for a sustainable agriculture and environment. International Nature Farming Research Center, Atami, Japan. 31 Mar. 2008. <http://bokashicenter. com/parrhigabkltCF1\%20on\%20EM.pdf>.

Horwath, W.R. and E.A. Paul. 1994. Microbial biomass, p. 753-773. In: Weaver, R.W., S. Angle, P. Bottomley, D. Bezdicek, S. Smith, A.
Tabatabai, and A. Wollum. (eds.). Methods of soil analysis. Part 2. Soil Sci. Soc. Am., Madison, WI.

Ingham, E. 2000. Brewing compost tea. Kitchen Gardener Magazine 29:16-19.

Kannangara, T., T. Forge, and B. Dang. 2006. Effects of aeration, molasses, kelp, compost type, and carrot juice on the growth of Escherichia coli in compost teas. Compost Sci. Util. 14:40-47.

Paschoal, A.D., S.K. Homma, A.B. Sanches, and M.C.S. Nogueira. 1998. Effect of EM on soil quality, fruit quality and yield of orange trees in a Brazilian citrus orchard. Fourth international conference on Kyusei nature farming, Proc. Conf., Paris, France, 19-21 June 1995. p. 103-111.

Sangakkar, R. and P. Weerasekera. 2001. Impact of effective microorganisms on nitrogen utilisation in food crops. Sixth International Conference on Kyusei Nature Farming. Proc. Conf., Pretoria, South Africa, 28-31 Oct. 1999. p. 63-69.

Sanwal, S.K., K. Laxminarayana, D.S. Yadav, N. Rai, and R.K. Yadav. 2006. Growth, yield, and dietary antioxidants of broccoli as affected by fertilizer type. J. Veg. Sci. 12:13-26.

Scheuerell, S. and W. Mahaffee. 2002. Compost tea: Principles and prospects for plant disease control. Compost Sci. Util. 10:313-338.

Shao, X.H., D.Y. Liu, P. Jiang, and W.L. Cao. 2003. Control of secondary salinization in soils through effective microbes. Seventh international conference on Kyusei nature farming, Proc. Conf., Christchurch, New Zealand, 15-18 Jan. 2002. p. 155-159.

Sturz, A.V., D.H. Lynch, R.C. Martin, and A.M. Driscoll. 2006. Influence of compost tea, powdered kelp, and ManzateReg. 75 on bacterialcommunity composition, and antibiosis against Phytophthora infestans in the potato phylloplane. Can. J. Plant Pathol. 28:52-62.

Tokeshi, H., M.A.T. Lima, and M.J.A. Jorge. 1996. Effect of EM and green manure on soil productivity in Brazil. Third international conference on Kyusei nature farming, Proc. Conf., Santa Barbara, California. 5-7 Oct. 1993. p. 193-202.

Vance, E.D. and P.C. Brooks. 1987. Measurement of microbial biomass in soil. Institute of Terrestrial Ecology, Symposium no. 18, Merlewood Research Station, UK, 19-20 Nov. 1985.

Wang, R., H.L. Xu, M.A.U. Mridha, S. Kato, K. Katase, and H. Umemura. 1999. Effects of organic fertilization and microbial inoculation on leaf photosynthesis and fruit yield of tomato plants. Jpn. J. Crop. Sci. 68:28-29. 